\title{
PENGEMBANGAN MEDIA PEMBELAJARAN INTERAKTIF PADA MATA PELAJARAN AGAMA ISLAM SISWA SD
}

\author{
Fadhilatun Mahfudzah ${ }^{1}$, Abdul Hamid $K^{2}$, Samsidar Tanjung ${ }^{3}$ \\ ${ }^{I}$ SD IKAL Medan, Sumatera Utara \\ ${ }^{2}$ FT Universitas Negeri Medan, Sumatera Utara \\ ${ }^{3}$ FIS Universitas Negeri Medan, Sumatera Utara \\ fadhilatun@gmail.com
}

\begin{abstract}
Abstrak: Tujuan penelitian ini adalah: (1) menghasilkan media pembelajaran shalat fardu berbasis Macromedia, (2) mengetahui apakah penggunaan media pembelajaran shalat fardu berbasis pembelajaran interaktif dapat meningkatkan hasil belajar agama islam siswa. Penelitian pengembangan yang menggunakan model pengembangan Borg dan Gall yang dipadu dengan rancangan pembelajaran model Dick and Carey. Hasil penelitian menunjukkan (1) uji ahli materi mata pelajaran Agama Islam berada pada kualifikasi sangat baik (91,33 \%), (2) uji ahli desain pembelajaran berada pada kualifikasi sangat baik (91,33\% \%), (3) uji ahli ahli media/desain grafis pembelajaran berada pada kualifikasi sangat baik (91,43 \%), (4) uji coba perorangan berada pada kualifikasi sangat baik (94.82\%), uji coba kelompok berada pada kualifikasi sangat baik (89,88\%), uji coba lapangan berada pada kualifikasi sangat baik (89,68\%). Hasil uji efektifitas menunukkan bahwa data $t$ hitung $=16,32$ t tabel0,05 $(2,49)=1,67$ maka $t$ hitung $(16,32)>t$ tabel $(1,67)$ untuk taraf signifikansi $(\alpha=0,05)$ atau dengan kata lain Ha diterima dan Ho ditolak, efektifitas penggunaan media pembelajaran sebesar 85,00 \%, tanpa media yaitu 75,90 $\%$. Data ini membuktikan bahwa penggunaan media pembelajaran interaktif shalat fardhu lebih efektif dalam meningkatkan hasil belajar siswa dari pada tanpa menggunakan media pembelajaran interaktif.
\end{abstract}

Kata Kunci: media pembelajaran interaktif, pelajaran agama islam, shalat fardu

Abstract: The purpose of this study are: (1) to produce Macromedia based fardu prayer learning media, (2) to find out whether the use of fardu prayer learning media based on interactive learning can improve students' Islamic religious learning outcomes. Development research using the Borg and Gall development model combined with the Dick and Carey model learning design. The results showed (1) the material expert test of Islamic subjects was in very good qualification (91.33\%), (2) the learning design expert test was in very good qualification (91.33\%), (3) expert test learning media / graphic design experts are in very good qualifications (91.43\%), (4) individual trials are in very good qualifications (94.82\%), group trials are in very good qualifications (89.88\%), test the field try is in very good qualification (89.68\%). The effectiveness test results show that the data $t$ count $=16.32 t$ table $0.05(2.49)=1.67$ then $t$ count $(16.32)>t$ table $(1.67)$ for the significance level $(\alpha=0.05)$ or in other words Ha is accepted and Ho is rejected, the effectiveness of the use of learning media is $85.00 \%$, without media that is $75.90 \%$. This data proves that the use of interactive learning media fardhu prayer is more effective in improving student learning outcomes than without using interactive learning media.

Keywords: interactive learning media, Islamic religious studies, fard prayer

\section{PENDAHULUAN}

Terminologi pendidikan Agama Islam berorientasi tidak hanya sekedar memberikan ilmu pengetahuan agama, tetapi lebih menekankan kepada aspek mendidik dengan arah pembentukan pribadi Muslim yang ta'at, berilmu dan beramal shalih. Pendidikan Agama Islam merupakan bidang studi yang dipelajari di sekolah, mulai dari tingkat Taman kanak-kanak hingga ke Perguruan Tinggi. Hal ini menunjukkan betapa pentingnya pendidikan Agama Islam dalam rangka pembentukan suatu 
kepribadian yang sesuai dengan tujuan dan tuntunan serta falsafah bangsa dan Agama yang dianutnya. Oleh karena itu, dalam pelaksanaannya Pendidikan Agama Islam di sekolah mempunyai dasar-dasar yang cukup kuat.

Pada hakekatnya Pendidikan Agama Islam mempunyai tujuan yang hendak dicapai, baik itu tujuan yang bersifat umum maupun sifatnya khusus. Ahmad Supardi (1979: 179) mengemukakan bahwa tujuan pendidikan Agama Islam adalah membenamkan taqwa dan akhlak serta menegakkan kebenaran untuk membentuk manusia yang berkepribadian luhur menurut ajaran Islam. Sementara itu Ahmad D.Marimba yang dikutip oleh Ahmad Tafsir (1992: 46) berpendapat bahwa tujuan pendidikan Agama Islam adalah terbentuknya orang yang berkepribadian Muslim. H.M. Arifin (1993: 119) mengatakan bahwa tujuan pendidikan Agama Islam adalah untuk merealisasikan idealitas Islami.

Pembelajaran Pendidikan Agama Islam khususnya materi Sholat Fardhu. Berdasarkan hal tersebut penulis mengembangkan media pembelajaran interaktif pada materi keserasian gerakan dan bacaan shalat fardhu. Sehingga bagi siswa yang malas dan kurang mengerti terhadap penjelasan guru, apalagi yang tidak tertarik terhadap pelajaran agama islam karna dipandang kurang menarik sehingga timbul masalah dalam pemahaman siswa mereka dapat mengulang-ulang materi tersebut dirumah dengan bimbingan orang tua.

Ilmu Pengetahuan dan Teknologi mempunyai peran yang sangat penting dalam bidang pendidikan antara lain: a. Munculnya media massa, khususnya media elektronik sebagai sumber ilmu dan pusat pendidikan. Dampak dari hal ini adalah guru bukannya satusatunya sumber ilmu pengetahuan.b. Munculnya metode-metode pembelajaran yang baru, yang memudahkan siswa dan guru dalam proses pembelajaran. Dengan kemajuan teknologi terciptalah metode-metode baru yang membuat siswa mampu memahami materimateri yang abstrak, karena materi tersebut dengan bantuan teknologi bisa dibuat abstrak.c. Sistem pembelajaran tidak harus melalui tatap muka. Kemajuan teknologi proses pembelajaran tidak harus mempertemukan siswa dengan guru, tetapi bisa juga menggunakan jasa pos internet dan lain-lain.
Model pembelajaran Interaktif adalah suatu cara atau teknik pembelajaran yang digunakan guru pada saat menyajikan bahan pelajaran dimana guru pemeran utama dalam menciptakan situasi interaktif yang edukatif, yakni interaksi antara guru dengan siswa, siswa dengan siswa dan dengan sumber pembelajaran dalam menunjang tercapainya tujuan belajar. Menurut Syah (1998) proses belajar mengajar keterlibatan siswa harus secara totalitas, artinya melibatkan pikiran, penglihatan, pendengaran dan psikomotor (keterampilan, salah satunya sambil menulis). Dalam proses mengajar seorang guru harus mengajak siswa untuk mendengarkan, menyajikan media yang dapat dilihat, memberi kesempatan untuk menulis dan mengajukan pertanyaan atau tanggapan sehingga terjadi dialog kreatif yang menunjukan proses belajar mengajar yang interaktif.

Melalui penggunaan media maka motivasi belajar akan meningkat yang diikuti dengan peningkatan prestasi belajar. Sebagaimana hasil penelitian James Kulik (Heinich, 1996: 232) menyimpulkan bahwa pembelajaran berbasis komputer membantu meningkatkan rata-rata prestasi siswa 10\%-18\% dibandingkan dengan pembelajaran konvensional. Thomson (Walker \& Hess, 1984: 121) mengatakan bahwa penggunaan komputer dalam pembelajaran dapat memberi manfaat, yakni dapat meningkatkan motivasi belajar siswa. Siswa menikmati kerja komputer dan ingin menghabiskan waktu karena komputer memberikan tantangan (yaitu pekerjaan yang tidak terlalu sulit dan tidak terlalu mudah) disamping itu komputer dapat menampilkan perpaduan antara teks, gambar, animasi, gerak dan suara secara bersamaan atau saling bergantian.

Ada beberapa media yang dapat digunakan untuk mengembangkan media pembelajaran sehingga dapat membantu terlaksananya kegiatan belajar mengajar yaitu Adobe ImageReady, Macromedia Director, Corel Rave, 3D Studio Max, Corner-A ArtStudio, Flash CS4, Alligator Flash Designer, Easy GIF Animator 5 pro, AnimPixels. Tetapi dalam penelitian ini penulis menggunakan Macromedia Flash yaitu salah satu media yang dapat digunakan untuk membantu kegiatan pembelajaran adalah Macromedia Flash.

Macromedia Flash adalah sebuah program mutimedia dan animasi yang 
keberadaannya ditujukan bagi pecinta desain dan animasi untuk berkreasi membuat aplikasiaplikasi unik, animasi-animasi interaktif pada halaman web, film animasi kartun, presentasi bisnis maupun kegiatan. Disamping itu, dengan menggunakan secara optimal kemampuan penggunaan fasilitas menggambar dan bahasa pemrograman pada Flash (action script) ini kita mampu membuat game-game yang menarik.

Dengan menggunakan aplikasi tersebut untuk mendesain pembelajaran interaktif dan menarik yang dapat menimbulkan minat siswa sehingga media ini dapat mengoptimalkan dalam membantu minat dan meningkatkan pemahaman siswa serta merangsang pikiran siswa terhadap materi pelajaran. Dalam uji coba lapangan, sujito (2008), media interaktif terbukti mampu meningkatkan antusiasme siswa untuk terus belajar. Hal ini diperkuat oleh pendapat Kristiningrum (2007), multimedia yang dibuat bermanfaat untuk meningkatkan motivasi belajar siswa melalui pengembangan dan penciptaan sarana belajar, sumber belajar, serta menunjukkan kemajuan teknologi yang semakin pesat. $\mathrm{CD}$ yang dihasilkan dapat dijadikan sebagai variasi sarana pembelajaran dan meningkatkan kreativitas serta memotivasi siswa untuk terus belajar supaya dapat memenuhi tuntutan perkembangan zaman. Dari penjelasan tersebut, maka kehadiran media pembelajarn interaktif disekolah saat ini merupakan hal yang berguna bagi proses pembelajaran.

Keefektifan penggunaan media interaktif dalam proses pembelajaran dikelas juga dikemukakan oleh Dwiyono (2009), keefektifan pembelajaran terjadi karena siswa dapat melihat berbagai bentuk data baik gambar, teks, suara, gerak, dan peragaan mengenai prosedur pelaksanaan tune up, sehingga memungkinkan siswa lebih menguasai materi pembelajaran.

Berdasarkan pada karakteristik siswa sekolah dasar yaitu pada usia tersebut anak diharapkan memperoleh dasar-dasar pengetahuan yang dianggap penting untuk keberhasilan penyesuaian diri pada kehidupan dewasa dan mempelajari berbagai keterampilan penting tertentu baik keterampilan kurikuler maupun ekstrakurikuler. Para pendidikan juga memandang periode ini sebagai periode kritis dalam dorongan berprestasi, suatu masa dimana anak membentuk kebiasaan untuk mencapai sukses, tidak sukses atau sangat sukses. Telah dilaporkan bahwa pada masa kanak-kanak mempunyai korelasi yang tinggi dengan perilaku berprestasi pada masa dewasa. (Elizabeth B. Hurlock, tt:146). Sejalan dengan hal tersebut diatas Penggunaan media pembelajaran interaktif pada siswa kelas 3 di SD IKAL yaitu pada usia 8-9 tahun juga merupakan hal yang mendukung pembelajaran dan peningkatan prestasi belajar siswa.

\section{Hakikat Media Pembelajaran Interaktif}

Perkembangan ilmu pengetahuan dan teknologi semakin mendorong upaya-upaya pembaharuan dalam pemanfaatan hasil-hasil teknologi dalam proses belajar mengajar. Para guru dituntut agar mampu menggunakan alatalat yang dapat disediakan oleh sekolah, dan tidak tertutup kemungkinan bahwa alat-alat tersebut sesuai dengan perkembangan dan tuntutan zaman. Guru sekurang-kurangnya dapat menggunakan alat yang murah dan bersahaja tetapi merupakan keharusan dalam upaya mencapai tujuan pengajaran yang diharapkan.

Disamping mampu menggunakan alatalat yang tersedia, guru juga dituntut untuk dapat mengembangkan alat-alat yang tersedia, guru juga dituntut untuk dapat mengembangkan keterampilan membuat media pengajaran yang akan digunakannya apabila media tersebut belum tersedia.

Untuk itu guru harus memiliki pengetahuan yang cukup tentang media pengajaran, yang meliputi:

1. Media sebagai alat komunikasi guna lebih mengefektifkan proses belajar mengajar;

2. Fungsi media dalam rangka mencapai tujuan pendidikan;

3. Seluk-beluk proses belajar;

4. Hubungan antara metode mengajar dan media pendidikan;

5. Nilai atau manfaat media pendidikan dalam pengajaran;

6. Pemilihan dan penggunaan media pendidikan

7. Berbagai jenis alat dan teknik media pendidikan;

8. Media pendidikan dalam setiap mata pelajaran;

9. Usaha inovasi dalam media pendidikan. (Azhar Arsyad, 2000:2)

Dalam dunia pendidikan kemutakhiran teknologi komputer memungkinkan pengemasan, pengkajian, dan pembuatan media 
pembelajaran yang memuat unsur text, graphic, audio, dan video dalam satu program. Kombinasi grafik, teks, suara, video, dan animasi didefinisikan sebagai multimedia oleh Azhar Arsyad (2005 : 171).

Dalam Pengembangan instruksional yang tujuan akhirnya adalah memudahkan pebelajar untuk belajar, media pembelajaran sangat diperlukan. Dimana kata media memiliki multiarti. Diantaranya yaitu :

1. Sudjana (2005) menjelaskan bahwa media merupakan alat komunikasi dan sumber informasi. Dimana bahwa media itu merupakan alat untuk menyampaikan pesan kepada penerima.

2. Purwanto (2004) memberikan kesimpulan atas pembahasannya mengenai media pembelajaran, bahwa media merupakan wadah dari pesan yang ole sumber atau penyalurannya yang ingin diteruskan kepada sasaran atau penerima pesan tersebut, materi yang ingin disampaikan adalah pesan pembelajaran, dan tujuan yang ingin dicapai adalah terjadinya proses belajar.

3. AECT (dalam Haryoso 2002) memaknai media sebagai segala bentuk yang dimanfaatkan dalam proses penyaluran informasi.

4. Gagne menyatakan bahwa media adalah berbagai jenis komponen dalam lingkungan siswa yang dapat merangsangnya untuk belajar, sementara itu Briggs berpendapat bahwa media adalah segala alat fisik yang dapat menyajikan pesan serta merangsang siswa untuk belajar (Arif S. Sadiman, 2003:6).

Berdasarkan beberapa pengertian diatas dapat disimpulkan bahwa media adalah segala sesuatu yang dapat digunakan atau dimanfaatkan dalam proses penyaluran informasi.

Kemp (1994) mengklasifikasikan media kedalam beberapa kategori media seperti $: 1$. Real things termasuk didalamnya pembicara tamu, objek dan model yang merupakan stimulasi dari objek sebenarnya, 2. Two Dimensional Display Materials, seperti kertas hasil foto copy atau print, papan tulis atau flipchart, diagram, chart, gambar, foto, lembar kerja, CD-Room, dan foto CD, 3. Audio Recording, seperti audiocassette recording dan audioCD recording, 4. Projected still pictures, termasuk didalamnya overhead transparancies, computer-generated image, slides, dan filmstrips. 5. Projected moving pictures, seperti film dan videotape, 6. Combinations of media, yang merupakan gabungan dari beberapa media, 7. Interactive technologies, termasuk computer based instruction (CBI) dan aplikasi multimedia.

Smaldino (2008) juga mengemukakan lima tipe dasar media, yaitu 1. Text, yang dapat disajikan dalam berbagai format seperti : buku, poster, papan tulis, layar computer dan sebagainya. 2. Audio, termasuk didalanya segala sesuatu yang dapat didengar seperti suara manusia, music, mesin dan sebagainya. 3. Visual, termasuk diagram dalam poster, gambar dipapan tulis, foto, grafik di buku, kartun dan sebagainya, 4. Manipulative, yaitu benda tiga dimensi yang dapat disentuh, dan 5.People, yaitu seperti guru, siswa, atau ahli bidang studi.

Penggunaan media pembelajaran pada tahap orientasi pembelajaran sangat membantu keefektifitasan proses pembelajaran dan penyampaian pesan isi pembelajaran pada saat ini. Disamping membangkitkan motivasi dan minat siswa, media pembelajaran juga dapat membantu siswa meningkatkan pemahaman penyajian data dengan menarik dan terpercaya, memudahkan penafsiran data dan pemadatan informasi.

Kehadiran media sangat dibutuhkan dalam pembelajaran sebagaimana yang dikemukakan dalam Sadiman (2005:17) mengatakan secara umum media pendidikan mempunyai fungsi sebagai berikut :

1. Memperjelas penyajian pesan agar tidak terlalu bersifat verbal

2. Mengatasi keterbatasan ruang, waktu dan daya indera

3. Penggunaan media pendidikan secara tepat dan bervariasi dapat mengatasi sikap pasif anak didik.

4. Dengan sifat yang unik pada setiap siswa ditambah lagi dengan lingkungan dan pengalaman yang berbeda, sedangkan kurikulum dan materi pendidikan ditentukan sama untuk setiap siswa, maka guru banyak mengalami kesulitan bilamana semua itu harus diatasi sendiri. Hal ini akan lebih sulit bila latar belakang lingkungan guru dengan siswa berbeda. Masalah ini dapat diatasi dengan media pendidikan, yaitu dengan kemampuannya dalam :

a. Memberikan perangasangan yang sama

b. Mempersamakan pengalaman

c. Menimbulkan persepsi yang sama 
Menurut Derek Rowntree dalam Ahmad Rohani (1997 : 8) mengatakan bahwa media pembelajaran memiliki beberapa fungsi yaitu:1. Membangkitkan motivasi belajar, 2 . Mengulang apa yang dipelajari, 3. Menyediakan stimulus belajar, 3. Mengaktifkan respon peserta didik, 4. Memberikan balikan dengan segera,5. Menggalakkan latihan yang serasi.

Dalam merencanakan dan melaksanakan aktivitas pembelajaran, setiap guru dituntut untuk dapat mempersiapkan dan memfungsikan segala unsur yang menunjang kelancaran proses pembelajaran agar dapat berjalan dengan efektif dan efisien. Sebagai salah satu unsur yang menunjang dalam pembelajaran, guru dituntut agar mengetahui dan merancang pemakaian media pembelajaran serta dapat mengetahui fungsi dan kegunaan media tersebut.

Menurut Sadiman (2003) fungsi atau kegunaan media antara lain: 1. Membuat konkrit konsep yang abstrak, 2. Membawa objek yang berbahaya atau sukar didapat kedalam lingkungan belajar, 3. Menampilkan objek yang terlalu besar, 4. Menampilkan objek yang tidak dapat diamati oleh mata telanjang, 5 . Mngamati gerakan yang terlalu cepat, 6 . Memungkinkan siswa berinteraksi langsung dengan lingkungannya, 7. Memungkinkan kesegara pengamatan belajar siswa, 8 . Membangkitkan motivasi belajar, 9. Menyajikan pesan atau informasi belajar secara konsisten dan dapat diulangi walaupun disimpan menurut kebutuhan, 10. Menyajikan pesan atau informasi belajar secara serempak, membatasi batasan waktu maupun ruan, 11.Mengontrol arah maupun kecepatan belajar siswa.

Media interaktif digolongkan sebagai media konstruktifistik yang terdiri dari pembelajaran, peserta didik dan proses pembelajaran. Dalam proses pembelajaran teknologi seperti computer, adalah alat dalam multimedia dan jaringan web terluas didunia yang sangat besar pengaruhnya terhadap peserta didik dalam proses pembelajaran.

Pengertian interaktif terkait dengan komunikasi dua arah atau lebih dari komponenkomponen komunikasi. Komponen komunikasi dalam media interaktif (berbasis computer) adalah hubungan antara manusia (sebagai user/pengguna produk) dan computer (software/aplikasi/produk dalam format file tertentu, biasanya dalam bentuk CD). Dengan demikian produk/CD/aplikasi yang diharkan memliki hubungan dua arah atau timbal balik antara software atau aplikasi dengan usernya. Interaktifitas dalam multimedia diberikan batasan sebagai berikut: 1. Pengguna (user) dilibatkan untuk berinteraksi dengan program aplikasi, 2. Aplikasi informasi interaktif bertujuan agar pengguna bisa mendapatkan hanya informasi yang diinginkan saja tanpa harus melahap semuanya. Berdasarkan pengertian tersebut maka dapat disimpulkan bahwa multimedia interaktif adalah suatu tampilan multimedia yang dirancang oleh desainer agar tampilannya memenuhi fungsi menginformasikan pesan dan memiliki interaktifitas kepada penggunanya (user).

Berdasarkan uraian tersebut multimedia pembelajaran dapat diartikan sebagai system komunikasi interaktif berbasis computer dalam suatu penyajian secara terintegrasi. Istilah berbasis computer berarti bahwa program multimedia menggunakan computer dalam menyajikan pembelajaran. Sedangkan terintegrasi berarti bahwa multimedia pembelajaran dapat menampilkan teks, gambar, audio, dan video atau animasi dalam satu kali tayang presentasi.

\section{Hakikat Mata Pelajaran Agama Islam}

Belajar merupakan sebuah proses yang kompleks yang terjadi pada semua orang dan berlangsung seumur hidup, dari dalam kandungan hingga ke liang lahat. Tanda bahwa seseorang telah belajar adalah adanya perubahan tingkah laku didalam dirinya. Dalam Teori Belajar dan Pembelajaran, Eveline Siregar dan Hartini Nara (2010: 5) menuliskan belajar adalah suatu aktifitas mental (psikis) yang berlangsung dalam interaksi dengan lingkungannya yang menghasilkan perubahan yang bersifat relative konstan.

Berikut ini adalah beberapa definisi belajar yang dikemukakan oleh para ahli, yaitu : menurut James O. Whittaker, belajar adalah proses dimana tingkah laku ditimbulkan atau diubah melalui latihan atau pengalaman. "Learning may be defined as the process by which behavior originates or is altered through training or experience". Dalam bukunya Educational Psychology, Cronbach menyatakan : "learning is shown by a change in behavior as a result of experience." Belajar yang sebaikbaiknya adalah dengan mengalami dan dalam 
mengalami itu si pelajar mempergunakan panca inderanya".(Soemanto, 1983:99).

Kingsley mengemukakan bahwa: "learning is the process by which behavior (in the broader sense) is originated or changed through practice or training". Belajar adalah proses dimana tingkah laku (dalam arti luas) ditimbulkan atau diubah melalui latihan atau pelatihan (Sumanto, 1984:99).

Slameto (2002:2) mendefiniskan belajar adalah suatu proses usaha yang dilakukan seseorang untuk memperoleh suatu perubahan tingkah laku yang baru secara keseluruhan, sebagai hasil pengalamannya sendiri dalam interaksi dengan lingkungannya.

Hakim (2002), belajar adalah suatu proses perubahan dalam kepribadian manusia, dan perubahan tersebut ditampakkan dalam bentuk peningkatan kualitas dan kuantitas tingkah laku seperti peningkatan kecakapan, pengetahuan, sikap, kebiasaan, pemahaman, ketrampilan, daya fikir, dan lain-lain kemampuannya.

Moh. Uzer Usman (2002:5), berpendapat bahwa belajar adalah proses perubahan tingkah laku pada diri individu karena adanya interaksi antar individu dan interaksi antara individu dengan lingkungannya. Hal ini berarti bahwa seseorang yang telah mengalami proses belajar maka akan terjadi perubahan tingkah lakunya, baik dari aspek pengetahuan, keterampilan, maupun sikapnya.

Hilgard dan Brower yang dikutip oleh Oemar Hamalik (2002: 45), mempunyai pendapat lain tentang definisi belajar, menurutnya belajar adalah perubahan dalam perbuatan melalui aktivitas, praktek, dan pengalaman.

Pendidikan Agama Islam adalah usaha sadar untuk menyiapkan siswa dalam meyakini, memahai, menghayati serta mengamalkan agama islam melalui kegiatan bimbingan, pengajaran dan atau latihan dengan memperlihatkan tuntunan untuk menghormati agama lain dalam hubungan kerukunan antar umat beragama dalam masyarakat untuk mewujudkan persatuan nasional. (Muhaimin, 2001:75).

Menurut Abdullah (1991), pendidikan Islam adalah pengaturan pribadi dan masyarakat sehingga dapat memeluk islam secara logis dan sesuai secara keaeluruhan baik dalam kehidupan individu maupun kolektif.
Pendidikan Agama Islam Menurut Arif (2008: 35-36) adalah rangkaian proses transformasi dan internalisasi ilmu pengetahuan dan nilai-nilai pada anak didik melalui pertumbuhan dan perkembangan potensi fitrahnya, baik aspek spiritual, intelektual, maupun fisiknya, guna keselarasan dan kesempurnaan hidup dalam segala aspeknya sesuai dengan nilai-nilai ajaran islam. Sedangkan tujuan pendidikan Agama Islam sebagaimana yang dirumuskan dalam Konferensi Pendidikan Islam sedunia adalah "menciptakan manusia yang baik dan benar, yang mengabdi kepada Allah dalam pengertian yang sebenar-benarnya, membangun struktur kehidupan duniawinya sesuai dengan syariat dan melaksanakannya untuk menopang keimanannya (Siddik, 2006:46) sedangkan menurut Nata (2009:20) Pendidikan Agama Islam atau Ilmu Pendidikan Islam adalah "ilmu yang membahas berbagai teori, konsep dan desain tentang berbagai aspek atau komponen pendidikan: visi, misi, tujuan, kurikulum, proses belajar mengajar dan sebagainya yang didasarkan pada nilai-nilai ajaran islam sebagaimana terdapat dalam Al-Qur'an dan AsSunah.

Rumusan masalah penelitian ini adalah: (1) bagaimana mengembangkan media pembelajaran interaktif pada mata pelajaran agama islam?; (2) Bagaimana mengimplementasikan media pembelajaran interaktif pada mata pelajaran agama islam di?; (3) Apakah media pembelajaran interaktif pada mata pelajaran agama Islam dapat meningkatkan hasil belajar siswa?

\section{METODE}

Penelitian ini dilakukan di SD Swasta Ikal Medan yang terletak dijalan Jongkong No. 23 B Kecamatan Medan Helvetia pada siswa kelas 3. Model pengembangan yang digunakan dalam penelitian pengembangan media pembelajaran interaktif dalam pelajaran Agama Islam materi sholat fardhu ini yaitu model pengembangan Borg and Gall (2003). Yang dipadu dengan model pengembangan Dick and Carey (2005).

$$
\text { Adapun langkah-langkah dalam }
$$$$
\text { pengembangannya yaitu : }
$$

1. Melakukan penelitian pendahuluan, yang meliputi :

a. Identifikasi kebutuhan Pembelajaran dan menetukan SK mata pelajaran 
b. Melakukan analisis pembelajaran

c. Mengidentifikasi karakteristik dan perilaku awal peserta didik

d. Menulis kompetensi dasar dan indikatornya

2. Menulis tes acuan patokan: menyusun strategi pembelajaran yang diwujudkan dalam bentuk silabus dan satuan pembelajaran.

a. Mengembangkan materi pembelajaran

b. Membuat desain software meliputi pembuatan naskah dan storyboard

3. Pengumpulan bahan yang meliputi

a. Pembuatan dan pengumpulan gambar

b. Perekaman dan pengumpulan audio

4. Mengembangkan dan membuat media pembelajaran interaktif

5. Review dan uji coba produk

Prosedur pengembangan yang dilakukan untuk menghasilkan produk media pembelajaran multimedia interaktif di bagi menjadi 5 tahap yaitu : tahap pertama pembuatan desain software, tahap dua pengumpulan bahan, tahap ketiga membuat dan memproduksi media pembelajaran interaktif, dan tahap keempat yaitu review atau uji lapangan dalam rangka evaluasi formatif dan revisi produk. Evaluasi formatif terus berlangsung selama proses pengembangan mulai dari tahap analisis, desain, produksi maupun implementasi sampai diperoleh hasil yang sesuai dengan tujuan yang telah ditetapkan, yang terakhir yaitu uji keefektifan produk.

\section{Teknik Analisis Data}

Analisis data dalam penelitian ini menggunakan analisis deskriptif kuantitatif. Semua data yang terkumpul dianalisis dengan teknik statistic deskriptif yang secara kuantitatif dipisahkan menurut kategori untuk mempertajam penilaian dalam menarik kesimpulan.

Data kualitatif yang berupa pernyataan sangat kurang baik, kurang baik, sedang, baik dan sangat baik diubah menjadi data kuantitatif dengan skala nilai 1-5 Hasilnya dirata-rata dan digunakan untuk menilai kualitas software pembelajaran. Untuk melihat implementasi dari penggunaan media pembelajaran interaktif tersebut menggunakan rumus keefektifan media interaktif menggunakan rumus perhitungan efektifitas berikut (Sugiyono, 2007) :

$$
\begin{aligned}
& X=\frac{\text { Jumlah skor yang diperoleh }}{\text { Jumlah skor ideal seluruh item }} \times 100 \\
& X=\text { skor empiris } \\
& \text { Dengan kriteria penilaian sebagai berikut : }
\end{aligned}
$$

\section{Table 11 : Kriteria Penilaian}

\begin{tabular}{cll}
\hline Nilai & \multicolumn{1}{c}{ Kriteria } & \multicolumn{1}{c}{ Persentase } \\
\hline A & Sangat Baik & $81 \% \leq X \leq 100 \%$ \\
B & Baik & $61 \% \leq X \leq 80 \%$ \\
C & Sedang & $41 \% \leq X \leq 60 \%$ \\
D & Kurang Baik & $21 \% \leq X \leq 40 \%$ \\
E & Sangat kurang baik & $0 \% \leq X \leq 20 \%$ \\
\hline
\end{tabular}

Untuk menguji hipotesis yaitu dengan menggunakan metode Judgment Expert (uji pakar), ahli media pembelajaran, ahli materi pelajaran dan ahli design pembelajaran. Kepada sampel dari populasi yang akan diuji, diambil sekitar 15 orang sampel secara acak. Kemudian dilakukan uji coba penggunaan media pembelajaran interaktif . dengan asumsi tingkat kesalahan 5\%. Dalam pengajuan Persyaratan Analisis dilakukan Uji Normalitas Data, Untuk uji normalitas data digunakan uji Liliefors dengan hipotesis nol (Ho), kemudian dilakukan juga uji homogenitas. Menguji hipotesis dengan uji t, sebagai berikut :

Untuk menguji hipotesis digunakan rumus uji t pada taraf $\alpha=0,05$.

$$
\begin{aligned}
& \text { Dan rumus untuk uji t adalah } \\
& \mathrm{t}=\frac{\bar{X}_{1}-\bar{X}_{2}}{s \sqrt{\frac{1}{n_{1}}+\frac{1}{n_{2}}}} \\
& \text { dimana } S^{2}=\frac{\left(n_{1}-1\right) s_{1}^{2}+\left(n_{1}-1\right) s_{2}^{2}}{n_{1}+n_{2}-2}
\end{aligned}
$$

Untuk menguji peningkatan hasil belajar menggunakan tes hasil belajar.

\section{HASIL PENELITIAN Data Hasil Uji Coba Tahap IV Uji Coba
Lapangan}

Uji coba lapangan dilakukan di SD Swasta Ikal Medan. Uji coba lapangan dilakukan terhadap 50 siswa kelas III semester ganjil yang terdiri dari 2 kelas yakni kelas III-B sebanyak 25 orang dan III-C sebanyak 25 orang. Uji coba lapangan menghasilkan datadata yang nantinya akan mengukur kelayakan dari produk yang dikembangkan, serta untuk mengetahui bagaimana manfaat produk tersebut bagi pemakainya. Penilaian dari uji coba lapangan 50 orang siswa SD Swasta Ikal Medan. Hasil Uji uji coba lapangan berupa skor penilaian terhadap media pembelajaran 
interaktif Shalat Fardhu dengan aspek kualitas teknis/tampilan materi pembelajaran dan kualitas

Tabel 1. Skor Penilaian Media Pembelajaran Berbasis Macromedia Flash 8 Shalat Fardhu pada Uji Coba Lapangan di SD Swasta Ikal Medan Tentang Kualitas Materi Pembelajaran

\begin{tabular}{|c|c|c|c|c|c|c|c|c|}
\hline \multirow{2}{*}{ No } & \multirow{2}{*}{ Indikator Penilaian } & \multicolumn{5}{|c|}{ Responden } & \multirow{2}{*}{ Persentase } & \multirow{2}{*}{ Kriteria } \\
\hline & & 1 & 2 & 3 & 4 & 5 & & \\
\hline 1 & Kesesuaian Materi & & & & 2 & 48 & $95,56 \%$ & Sangat Baik \\
\hline 2 & Kejelasan Petunjuk Belajar & & & & 5 & 45 & $88,89 \%$ & Sangat Baik \\
\hline 3 & Kemudahan Memahami Kalimat & & & & 8 & 42 & $82,22 \%$ & Sangat Baik \\
\hline 4 & Kemudahan Memahami Pembelajaran & & & & 3 & 47 & $93,33 \%$ & Sangat Baik \\
\hline 5 & Ketepatan Urutan Penyajian & & & & 7 & 43 & $84,44 \%$ & Sangat Baik \\
\hline 6 & Kecukupan Latihan & & & & 8 & 42 & $82,22 \%$ & Sangat Baik \\
\hline 7 & Kejelasan Umpan Balik & & & & 5 & 45 & $88,89 \%$ & Sangat Baik \\
\hline 8 & Bantuan belajar dengan program & & & & 2 & 48 & $95,56 \%$ & Sangat Baik \\
\hline & Penilaian secara keselu & & & & & & $88,89 \%$ & Sangat Baik \\
\hline
\end{tabular}

Tabel 2. Skor Penilaian Media Pembelajaran Berbasis Macromedia Flash 8 Shalat Fardhu pada Uji Coba Lapangan Kecil di SD Swasta Ikal Medan Tentang Kualitas Materi Pembelajaran

\begin{tabular}{|c|c|c|c|c|c|c|c|c|}
\hline \multirow{2}{*}{ No } & \multirow{2}{*}{ Indikator Penilaian } & \multicolumn{5}{|c|}{ Responden } & \multirow{2}{*}{ Persentase } & \multirow{2}{*}{ Kriteria } \\
\hline & & 1 & 2 & 3 & 4 & 5 & & \\
\hline 1 & Keindahan Tampilan Layar & & & & 6 & 44 & $86.67 \%$ & Sangat Baik \\
\hline 2 & Keterbacaan teks & & & & 6 & 44 & $86.67 \%$ & Sangat Baik \\
\hline 3 & Kualitas gambar dan Animasi & & & & 8 & 42 & $82.22 \%$ & Sangat Baik \\
\hline 4 & Komposisi warna & & & & 3 & 47 & $93.33 \%$ & Sangat Baik \\
\hline 5 & Navigasi & & & & 1 & 49 & $97.78 \%$ & Sangat Baik \\
\hline 6 & Daya Dukung Musik & & & & 2 & 48 & $95.56 \%$ & Sangat Baik \\
\hline 7 & Interaksi & & & & 4 & 46 & $91.11 \%$ & Sangat Baik \\
\hline & Penilaian secara $\mathrm{l}$ & & & & & & $90.48 \%$ & Sangat Baik \\
\hline
\end{tabular}

Hasil penilaian uji lapangan terhadap dinyatakan sangat baik (100\%), Penilaian uji aspek kualitas materi pembelajaran terhadap perorangan terhadap aspek kualitas materi media pembelajaran interaktif menulis surat pembelajaran dan kualitas teknis/tampilan.

Tabel 3. Tingkat Kecenderungan Penilaian Pada Uji Coba Lapangan Terhadap Penilaian Aspek Kualitas Materi Pembelajaran

\begin{tabular}{clccc}
\hline No & \multicolumn{1}{c}{ Kategorisasi } & Rentang Skor & Frekuensi & Persentase \\
\hline 1 & Sangat baik & $80 \% \leq \mathrm{x} \leq 100 \%$ & 50 & $100, .00 \%$ \\
2 & Baik & $60 \% \leq \mathrm{x}<79 \%$ & 0 & $0,00 \%$ \\
3 & Sedang & $40 \% \leq \mathrm{x}<59 \%$ & 0 & $0,00 \%$ \\
4 & Kurang baik & $20 \% \leq \mathrm{x}<39 \%$ & 0 & $0,00 \%$ \\
5 & Sangat kurang baik & $0 \% \leq \mathrm{x}<19 \%$ & 0 & $0,00 \%$ \\
\hline \multicolumn{2}{r}{ Jumlah } & 50 & $100,00 \%$ \\
\hline
\end{tabular}

Tabel 4. Tingkat Kecenderungan Penilaian Pada Uji Coba Lapangan Terhadap Penilaian Aspek Kualitas Teknis/Tampilan

\begin{tabular}{rlccc}
\hline No & \multicolumn{1}{c}{ Kategorisasi } & Rentang Skor & Frekuensi & Persentase \\
\hline 1 & Sangat baik & $80 \% \leq \mathrm{x} \leq 100 \%$ & 50 & $100, .00 \%$ \\
2 & Baik & $60 \% \leq \mathrm{x}<79 \%$ & 0 & $0,00 \%$ \\
3 & Sedang & $40 \% \leq \mathrm{x}<59 \%$ & 0 & $0,00 \%$ \\
4 & Kurang baik & $20 \% \leq \mathrm{x}<39 \%$ & 0 & $0,00 \%$ \\
5 & Sangat kurang baik & $0 \% \leq \mathrm{x}<19 \%$ & 0 & $0,00 \%$ \\
\hline \multicolumn{5}{r}{ Jumlah } \\
\hline
\end{tabular}


Pada uji coba lapangan yang dilakan ukan pada 50 orang siswa SD Swasta Ikal Medan, tidak terdapat perbaikan atau tidak diadakan revisi IV pada tahap uji lapangan, yang berarti media pembelajaran interaktif telah siap diuji keefektifannya.

\section{Analisa Data Hasil Evaluasi Ahli Materi}

Tabel 5. Persentase Rata-rata Hasil Penilaian Terhadap Media Pembelajaran Berbasis Macromedia Flash 8 Shalat Fardhu Oleh Ahli Materi

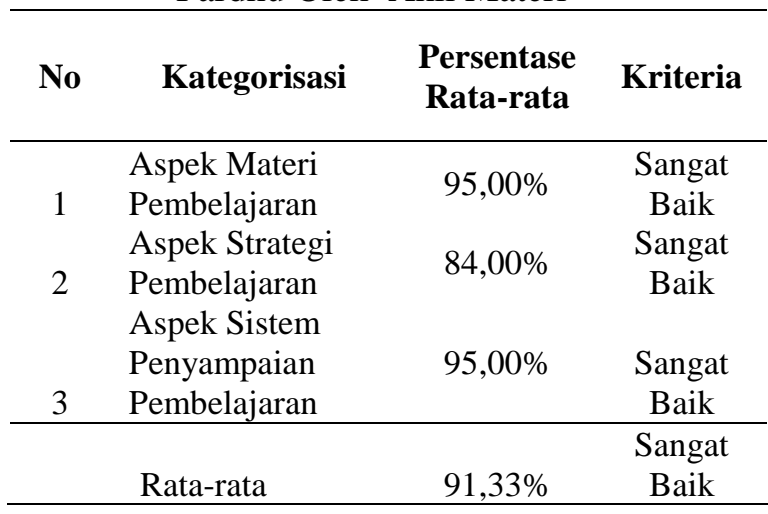
Analisa Data Hasil Evaluasi Ahli Desain
Pembelajaran

Tabel 6. Persentase Rata-rata Hasil Penilaian Terhadap Media Pembelajaran Berbasis Macromedia Flash 8 Shalat Fardhu Oleh Ahli Desain Pembelajaran

\begin{tabular}{clcc}
\hline No & Kategorisasi & $\begin{array}{c}\text { Persentase } \\
\text { Rata-rata }\end{array}$ & Kriteria \\
\hline \multirow{2}{*}{1} & $\begin{array}{l}\text { Kualitas desain } \\
\text { pembelajaran } \\
\text { Kualitas desain }\end{array}$ & $97.50 \%$ & $\begin{array}{c}\text { Sangat } \\
\text { Baik }\end{array}$ \\
2 & $\begin{array}{l}\text { Informasi } \\
\text { Kualitas desain }\end{array}$ & $88,57 \%$ & $\begin{array}{c}\text { Sangat } \\
\text { Baik } \\
\text { Sangat } \\
\text { Baik }\end{array}$ \\
& $\begin{array}{l}\text { Interaksi } \\
\text { Kualitas desain } \\
\text { Presentasi }\end{array}$ & $90,00 \%$ & $\begin{array}{c}\text { Sangat } \\
\text { Baik }\end{array}$ \\
\hline & Rata-rata & $90,89 \%$ & $\begin{array}{c}\text { Sangat } \\
\text { Baik }\end{array}$ \\
\hline
\end{tabular}

Analisa Data Hasil Evaluasi Ahli Media dan desain Grafis

Data hasil penelitian tentang persentase rata-rata hasil penilaian terhadap multimedia pembelajaran berbasis Macromedia Flash disajikan pada Tabel 7 berikut.
Tabel 7. Persentase Rata-rata Hasil Penilaian Terhadap Media Pembelajaran Berbasis Macromedia Flash 8 Shalat Fardhu Oleh Ahli Media dan Desain Grafis

\begin{tabular}{clcc}
\hline No & Kategorisasi & $\begin{array}{c}\text { Persentase } \\
\text { Rata-rata }\end{array}$ & Kriteria \\
\hline 1 & Pemrograman & $90.00 \%$ & $\begin{array}{c}\text { Sangat } \\
\text { Baik }\end{array}$ \\
\hline 2 & $\begin{array}{l}\text { Kualitas teknis } \\
\text { atau tampilan }\end{array}$ & $92.86 \%$ & $\begin{array}{c}\text { Sangat } \\
\text { Baik }\end{array}$ \\
\hline Rata-rata & $91,43 \%$ & $\begin{array}{c}\text { Sangat } \\
\text { Baik }\end{array}$ \\
\hline
\end{tabular}

\section{Analisa II : Analisa Data Uji Coba Tahap II Uji Coba Perorangan}

Tabel 8 berikut menunjukkan persentase rata-rata hasil penilaian pada uji coba perorangan di SD Swasta Ikal Medan kelas 3 semester ganjil terhadap aspek kualitas materi pembelajaran sebesar $92,50 \%$ dan aspek kualitas teknis atau tampilan sebesar 97,14\% dan masing-masing termasuk kategori sangat baik. Berdasarkan hasil penilaian pada media pembelajaran interaktif shalat Fardhu pada uji coba perorangan tidak terdapat perbaikan. Persentase rata-rata dari hasil penilaian ahli materi.

Tabel 8. Persentase Rata-rata Hasil Penilaian Terhadap Media Pembelajaran Berbasis Macromedia Flash 8 Shalat Fardhu Uji Coba Perorangan

\begin{tabular}{cccc}
\hline No & Kategorisasi & $\begin{array}{c}\text { Persentase } \\
\text { Rata-rata }\end{array}$ & Kriteria \\
\hline 1 & $\begin{array}{l}\text { Aspek kualitas } \\
\text { materi pembelajaran }\end{array}$ & $92.50 \%$ & $\begin{array}{c}\text { Sangat } \\
\text { Baik }\end{array}$ \\
\hline & $\begin{array}{l}\text { Aspek Kualitas } \\
\text { teknis atau tampilan }\end{array}$ & $97.14 \%$ & $\begin{array}{c}\text { Sangat } \\
\text { Baik }\end{array}$ \\
\hline & Rata-rata & $94.82 \%$ & $\begin{array}{c}\text { Sangat } \\
\text { Baik }\end{array}$ \\
\hline
\end{tabular}

\section{Analisa III : Analisa Data Uji Coba Tahap II Uji Coba Kelompok}

Tabel 9 berikut menunjukkan persentase rata-rata hasil penilaian pada uji kelompok di SD Swasta IKAL Medan kelas III semester ganjil terhadap aspek kualitas materi pembelajaran sebesar $88,33 \% \%$ dan aspek kualitas teknis atau tampilan sebesar $91,43 \%$ dan masing-masing termasuk kategori sangat baik. Berdasarkan hasil penilaian pada media pembelajaran interaktif shalat fardhu pada uji 
coba perorangan tidak terdapat perbaikan. Persentase rata-rata dari hasil uji kelompok di SD Swasta IKAL Medan.

Tabel 9. Persentase Rata-rata Hasil Penilaian Terhadap Media Pembelajaran Berbasis Macromedia Flash 8 Shalat Fardhu Uji Kelompok

\begin{tabular}{clcc}
\hline No & Kategorisasi & $\begin{array}{c}\text { Persentase } \\
\text { Rata-rata }\end{array}$ & Kriteria \\
\hline 1 & $\begin{array}{l}\text { Aspek kualitas } \\
\text { materi } \\
\text { pembelajaran }\end{array}$ & $88,33 \% \%$ & $\begin{array}{c}\text { Sangat } \\
\text { Baik }\end{array}$ \\
\hline 2 & $\begin{array}{l}\text { Aspek Kualitas } \\
\text { teknis atau } \\
\text { tampilan }\end{array}$ & $91,43 \%$ & $\begin{array}{c}\text { Sangat } \\
\text { Baik }\end{array}$ \\
\hline Rata-rata & $89,88 \%$ & $\begin{array}{c}\text { Sangat } \\
\text { Baik }\end{array}$ \\
\hline
\end{tabular}

\section{Analisa IV : Analisa Data Uji Coba Tahap II Uji Coba Lapangan}

Tabel 10 berikut menunjukkan persentase rata-rata hasil penilaian pada uji lapangan di SD Swasta IKAL Medan kelas 3 siswa berjumlah 50 orang semester ganjil terhadap aspek kualitas materi pembelajaran sebesar $88,89 \%$ dan aspek kualitas teknis atau tampilan sebesar 90,48\% dan masing-masing termasuk kategori sangat baik. Berdasarkan hasil penilaian pada media pembelajaran interaktif Shalat Fardhu pada uji lapangan tidak terdapat perbaikan. Persentase rata-rata dari hasil uji lapangan di SD Swasta IKAL Medan.

Tabel 10. Persentase Rata-rata Hasil Penilaian Terhadap Media Pembelajaran Berbasis Macromedia Flash 8 Shalat Fardhu Uji Lapangan

\begin{tabular}{clcc}
\hline No & Kategorisasi & $\begin{array}{c}\text { Persentase } \\
\text { Rata-rata }\end{array}$ & Kriteria \\
\hline 1 & $\begin{array}{l}\text { Aspek kualitas } \\
\text { materi } \\
\text { pembelajaran }\end{array}$ & $88,89 \%$ & $\begin{array}{c}\text { Sangat } \\
\text { Baik }\end{array}$ \\
\hline 2 & $\begin{array}{l}\text { Aspek Kualitas } \\
\text { teknis atau } \\
\text { tampilan }\end{array}$ & $90.48 \%$ & $\begin{array}{c}\text { Sangat } \\
\text { Baik }\end{array}$ \\
\hline & Rata-rata & $89.68 \%$ & $\begin{array}{c}\text { Sangat } \\
\text { Baik }\end{array}$ \\
\hline
\end{tabular}

\section{Uji Persyaratan Analisis \\ Uji Normalitas Data \\ Data Pretes}

Untuk uji normalitas data digunakan uji Liliefors dengan hipotesis nol (Ho) yang menyatakan bahwa sampel berasal dari populasi berdistribusi normal. Penerimaan dan penolakan Ho berdasarkan pada perbandingan harga $\mathrm{L}_{\text {hitung }}\left(\mathrm{L}_{\mathrm{h}}\right)$ dengan harga $\mathrm{L}_{\text {tabel }}\left(\mathrm{L}_{\mathrm{t}}\right)$ pada taraf signifikansi $\alpha$ sebesar 0.05 , apabila $\mathrm{L}_{\text {hitung }}$ $<\mathrm{L}_{\text {tabe }}$ maka data tersebut adalah berdistribusi normal. Uji normalitas dilakukan untuk kedua perlakuan, yaitu kelompok untuk kelas eksperimen dan kontrol.

Tabel 11. Hasil Belajar Shalat Fardhu Pretes yang Dibelajarkan dengan dan Tanpa Media Pembelajaran berbasis Macromedia Flash

\begin{tabular}{ccccc}
\hline Kelompok & $\mathbf{N}$ & Lhitung & $\begin{array}{c}\text { Ltabel } \\
(\alpha=0,05)\end{array}$ & $\begin{array}{c}\text { Kesim- } \\
\text { pulan }\end{array}$ \\
\hline Eksperimen & 25 & 0,1521 & 0,1730 & Normal \\
\hline Kontrol & 25 & 0,1452 & 0,1730 & Normal \\
\hline
\end{tabular}

Dari hasil perhitungan pada Tabel 4.45. di dapat $\mathrm{L}_{\text {hit }}=0,1521, \mathrm{~L}_{\text {tabel }}=0,1730$ maka $\mathrm{L}_{\mathrm{h}}(0,1521)$ $<\mathrm{L}_{\mathrm{t}}(0,1730)$ untuk kelompok eksperimen dan kelompok kontrol $\mathrm{L}_{\text {hit }}=0,1452, \mathrm{~L}_{\text {tabel }}=0,1730$ maka $\mathrm{L}_{\mathrm{h}}(0,1452)<\mathrm{L}_{\mathrm{t}}(0,1730)$ disimpulkan bahwa kedua data kelompok pembelajaran tersebut adalah berdistribusi normal untuk taraf signifikansi $(\alpha=0,05)$

\section{Nilai Posttes}

Uji normalitas dilakukan untuk kedua perlakuan, yaitu kelompok untuk kelas eksperimen dan kontrol.

Tabel 12 Hasil Belajar Shalat Fardhu Posttes yang Dibelajarkan dengan dan Tanpa Menggunakan Media Pembelajaran Interaktif berbasis Macromedia Flash

\begin{tabular}{lcccc}
\hline Kelompok & N & L $_{\text {hitung }}$ & $\begin{array}{c}\mathbf{L}_{\text {tabel }} \\
(\alpha=0,05)\end{array}$ & $\begin{array}{c}\text { Kesimpul } \\
\text { an- }\end{array}$ \\
\hline Eksperimen & 25 & 0,0907 & 0,1730 & Normal \\
\hline Kontrol & 25 & 0,1350 & 0,1730 & Normal \\
\hline
\end{tabular}

Dari hasil perhitungan pada Tabel 4.45. di dapat $\mathrm{L}_{\text {hit }}=0,0907, \mathrm{~L}_{\text {tabel }}=0,1730$ maka $\mathrm{L}_{\mathrm{h}}(0,0907)$ $<\mathrm{L}_{\mathrm{t}}(0,1730)$ untuk kelompok eksperimen dan kelompok kontrol $\mathrm{L}_{\text {hit }}=0,1452, \mathrm{~L}_{\text {tabel }}=0,1730$ maka $\mathrm{L}_{\mathrm{h}}(0,1350)<\mathrm{L}_{\mathrm{t}}(0,1730)$ disimpulkan bahwa kedua data kelompok pembelajaran tersebut adalah berdistribusi normal untuk taraf signifikansi $(\alpha=0,05)$

\section{Uji Homogenitas}

Data Pretest

Besarnya varians untuk kelompok eksperimen dan kelompok kontrol untuk $\mathrm{n}=25$, $s^{2}{ }_{1}=37,09, s^{2}{ }_{2}=56,55$.

Hasil perhitungan Uji Homogenitas t 
Tabel 13. Uji Homogenitas untuk Pretes

\begin{tabular}{lcccccc}
\hline Sampel ke & $\mathbf{N}$ & $\mathbf{S i}^{2}$ & $\mathbf{F}_{\text {hitung }}$ & $\mathbf{F}_{\text {tabel }}$ & $\begin{array}{c}\text { Keter } \\
\text { angan }\end{array}$ \\
\cline { 1 - 3 } Eksperimen & 25 & 37,09 & 0,66 & 1,96 & $\begin{array}{c}\text { Homo } \\
\text { gen }\end{array}$ \\
\hline Kontrol & 25 & 56,55 & 0,66 & &
\end{tabular}

Dengan $\alpha=0,05$, dari daftar distribusi

$\mathrm{F}$ dengan $\mathrm{dk}=\mathrm{n}-1$ didapat $\mathrm{F}_{0,05(24,24)}=1,96$ Ternyata $F_{\text {hitung }}<F_{\text {tabel }}(0,66<1,96)$ sehingga $H_{0}$ diterima yang berarti data berasal dari kelompok yang homogen.

\section{Data posttes}

Besarnya varians untuk kelompok eksperimen dan kelompok kontrol untuk $\mathrm{n} \mathrm{n}=25, s^{2}{ }_{1}=$ $28,17, s^{2}{ }_{2}=40,11$.

Tabel 14. Uji Homogenitas untuk Posttes

\begin{tabular}{|c|c|c|c|c|c|}
\hline Sampel ke & $\mathbf{N}$ & $\mathbf{S i}^{2}$ & $\mathbf{F}_{\text {hitung }}$ & $F_{\text {tabel }}$ & $\begin{array}{c}\text { Kete- } \\
\text { rang- } \\
\text { an }\end{array}$ \\
\hline $\begin{array}{c}\text { Eksperime } \\
\mathrm{n}\end{array}$ & 25 & 28,17 & \multirow[t]{2}{*}{0,70} & \multirow[t]{2}{*}{1,96} & \multirow{2}{*}{$\begin{array}{c}\text { Homo } \\
\text { gen }\end{array}$} \\
\hline Kontrol & 25 & 40,11 & & & \\
\hline
\end{tabular}

Dengan $\alpha=0,05$, dari daftar distribusi $\mathrm{F}$ dengan $\mathrm{dk}=\mathrm{n}-1$ didapat $\mathrm{F}_{0,05(24,24)}=1,96$ Ternyata $\mathrm{F}_{\text {hitung }}<\mathrm{F}_{\text {tabel }}(0,70<1,96)$ sehingga $\mathrm{H}_{0}$ diterima yang berarti data berasal dari kelompok yang homogen.

Berdasarkan hasil perhitungan diperoleh $\mathrm{t}_{\text {hit }}=20,69, \mathrm{t}_{\text {tabel } 0,05(2,49)}=1,67$ maka $\mathrm{t}_{\mathrm{h}}(20,69)$ $>t_{t}(1,67)$ untuk taraf signifikansi $(\alpha=0,05)$ maka dapat disimpulkan bahwa terdapat perbedaan yang signifikan sebelum pembelajaran dan setelah pembelajaran hasil belajar Agama Islam dengan materi Shalat Fardhu Kelas III SD Swasta IKAL TA. 2015/2016

Nilai Keefektifan media pembelajaran Agama Islam berbasis Macromedia Flash Professional 8 diperoleh sebagai berikut

$\mathrm{X}=\frac{\text { Jumlah skor yang diperoleh }}{\text { Jumlah skor ideal seluruh item }} \times 100 \%$

$$
X=\frac{2129}{2500} X 100 \%=85,00 \%
$$

Nilai Keefektifan tanpa media pembelajaran Agama Islam berbasis Macromedia Flash Professional 8 diperoleh sebagai berikut

$$
\mathrm{X}=\frac{1897}{2500} \mathrm{X} 100 \%=75,90 \%
$$

dengan efektifitas penggunaan media interaktif sebesar 85,00\%, dibandingkan dengan nilai keefektifan pembelajaran tanpa media yaitu $75,90 \%$, jadi dapat disimpulkan media pembelajaran Agama Islam berbasis Macromedia Flash Professional 8 lebih efektif digunakan untuk meningkatkan hasil belajar Agama Islam dengan materi shalat fardhu Kelas III SD Swasta IKAL Medan.

\section{PEMBAHASAN}

Penelitian dan pengembangan produk ini menghasilkan suatu produk berupa media pembelajaran interaktif bahasa Indonesia berbasis Macromedia Flash Professional 8 dengan materi shalat fardhu Kelas III SD Swasta IKAL

Untuk meningkatkan hasil belajar pengembangan media interaktif Agama Islam berbasis Macromedia Flash Professional 8 dengan materi shalat Fardhu Kelas III SD Swasta IKAL dilakukan beberapa tahapan yang dirujuk dari tahapan model pengembangan sistem pembelajaran (Instructional Systems Develovment / ISD) Dick, Carey, dan Carey (2001) berdasarkan 9 tahapan yaitu (1) analisis kebutuhan untuk menentukan tujuan. tujuan pembelajaran dapat diperoleh dari serangkaian tujuan pembelajaran yang ditemukan dari analisis kebutuhan, dari kesulitan-kesulitan warga belajar dalam praktek pembelajaran, dari analisis yang dilakukan oleh orang-orang yang bekerja dalam bidang, atau beberapa keperluan untuk pembelajaran yang aktual, (2) melakukan analisis pembelajaran yaitu menentukan keterampilan, pengetahuan, dan sikap yang disebut sebagai entry behavior (perilaku awal/masukan) yang diperlukan oleh warga belajar untuk memulai pembelajaran, (3) menganalisis warga belajar dan lingkungannya, meliputi keterampilan-keterampilan warga belajar yang ada saat ini, yang lebih disukai, dan sikap-sikap ditentukan berdasarkan karakteristik atau setting pembelajaran dan setting lingkungan tempat keterampilan diterapkan. Langkah ini adalah langkah awal yang penting dalam strategi pembelajaran, (4) merumuskan tujuan khusus, dengan mengidentifikasi keterampilan-keterampilan yang dipelajari, kondisi pencapaian unjuk kerja, dan kriteria pencapaian unjuk kerja. (5) mengembangkan instrumen penilaian, dengan membangkan produk evaluasi untuk mengukur kemampuan warga belajar melakukan tujuan pembelajaran. Penekanan utama berada pada hubungan perilaku yang tergambar dalam tujuan pembelajaran dengan untuk apa melakukan penilaian, (6) mengembangkan 
strategi pembelajaran, meliputi; kegiatan prapembelajaran (pre-activity), penyajian informasi, praktek dan umpan balik (practice and feedback, pengetesan (testing), dan mengikuti kegiatan selanjutnya. Strategi pembelajaran berdasarkan teori dan hasil penelitian, karakteristik media pembelajaran yang digunakan, bahan pembelajaran, dan karakteristik warga belajar yang menerima pembelajaran, (7) mengembangkan materi pembelajaran, produk pengembangan ini meliputi petunjuk untuk warga belajar, materi pembelajaran, dan soal-soal.. Pengembangan materi pembelajaran tergantung kepada tipe pembelajaran, materi yang relevan, dan sumber belajar yang ada disekitar perancang, (8) merancang \& mengembangkan Evaluasi Formatif, dan (9) merevisi Pembelajaran, data yang diperoleh dari evaluasi formative dikumpulkan dan diinterpretasikan untuk memecahkan kesulitan yang dihadapi warga belajar dalam mencapai tujuan. Bukan hanya untuk ini, singkatnya hasil evaluasi ini digunakan untuk merevisi pembelajaran agar lebih efektif. Tahapan-tahapan ini digunakan dalam proses pembelajaran sehingga dihasilkan media pembelajaran yang layak digunakan sesuai dengan karakteristik siswa dan bidang studi.

Menurut Latuheru (1988: 23), manfaat media pembelajaran yaitu: 1) media pembelajaran menarik dan memperbesar perhatian anak-anak didik terhadap materi pengajaran yang disajikan, 2) media pembelajaran mengurangi, bahkan dapat menghilangkan adanya verbalisme, 3) media pembelajaran mengatasi perbedaan pengalaman belajar berdasarkan latar belakang sosial ekonomi dari anak didik, 4) media pembelajaran membantu memberikan pengalaman belajar yang sulit diperoleh dengan cara yang lain, 5) media pembelajaran dapat mengatasi masalah batas-batas ruang dan waktu, 6) media pembelajaran dapat membantu perkembangan pikiran anak didik secara teratur tentang hal yang mereka alami, 7) media pembelajaran dapat membantu anak didik dalam mengatasi hal yang sulit nampak dengan mata, 8) media pembelajaran dapat menumbuhkan kemampuan berusaha sendiri berdasarkan pengalaman dan kenyataan, 9) media pembelajaran dapat mengatasi hal/peristiwa/kejadian yang sulit diikuti oleh indera mata, 10) media pembelajaran memungkinkan terjadinya kontak langsung antara anak didik, guru, dengan masyarakat, maupun dengan lingkungan alam di sekitar mereka.

Hardiyanto, (2011) dalam penelitian menunjukkan bahwa dengan pemanfaatan media pembelajaran Agama Islam materi shalat fardhu berbasis macromedia flash professional 8 sebagai media pembelajaran, dapat meningkatkan motivasi belajar siswa dari 49, $56 \%$ menjadi $67,33 \%$. Pengembangan desain pembelajaran digunakan sebagai pedoman dalam penyelenggaraan agar tercapai pembelajaran yang efektif, efisien dan berdaya guna. Macromedia Flash sering digunakan animator untuk membuat animasi interaktif maupun non interaktif, seperti animasi pada halaman web dan animasi kartun. Software ini mempunyai banyak keunggulan dibandingkan dengan software animasi lainnya diantaranya adalah program yang berorientasi objek, mampu mendesain gambar berbasis vector, kemampuannya menghasilkan animasi gerak dan suara.

Media pembelajaran khususnya untuk menarik minat belajar siswa dan menghilangkan kejenuhan siswa dalam mengikuti pembelajaran pelajaran Agama Islam pada materi shalat fardhu serta arus globalisasi teknologi dan informasi yang semakin maju perkembangannya, media pembelajaran berbasis macromedia flash mata pelajaran Agama Islam dipilih sebagai metode alternatif dalam pengembangan media pembelajaran, sehingga dengan adanya media tersebut maka hasil belajar siswa akan lebih tinggi dibandingkan dengan hasil belajar siswa yang diajarkan dengan cara konvensional.

Multimedia pembelajaran yang dikembangkan dikemas dalam bentuk kepingan compact disk (CD) dengan menggunakan macromedia flash Macromedia Flash Professional 8 profesional sebagai software utama dan program-program lain yangdiperlukan pendukung. Serta dapat disimpan di hard disk computer dan flashdisk.

Penggunaan multimedia pembelajaran ini memungkinkan peserta didik lebih mudah dalam belajar Agama Islam karena dilengkapi dengan warna, musik, film dan animasi, Serta memuat standar kompetensi, kompetensi dasar, dan indikator. Siswa dapat berinteraksi langsung dengan media pembelajaran, siswa juga dapat mengulang-ulang materi yang belum 
dipahaminya. Produk dapat digunakan secara fleksibel sesuai keinginan peserta didik dan dilengkapi latihan / evaluasi belajar. Media pembelajaran ini sangat praktis, karena dapat dibawa oleh siswa dan dapat dipelajari di rumah karena media pembelajaran initeraktif ini dalam bentuk flash. Media pembelajaran ini juga disertai dengan latihan-latihan berupa tes pilihan ganda yang memiliki durasi waktu dan kunci jawaban yang benar, sehingga siswa dapat mengetahui kesalahan yang telah dilakukan dalam mengerjakan soal latihan tersebut. Tanpa media pembelajaran proses belajar cenderung membosankan, karena pembelajaran menjadi satu arah guru aktif dan murid pasif menerima dan mengikuti apa yang disampaikan guru.

Media pembelajaran ini menggunakan teks, gambar, animasi, paduan warna sesuai keperluan, sehingga dapat memudahkan pemahaman, menarik perhatian, dan menyenangkan. Multimedia pembelajaran ini dapat digunakan untuk individu secara mandiri, maupun klasikal sesuai ketersediaan jumlah komputer. Atau juga bisa digunakan dengan bantuan fasilitas liquid crystal display (LCD) proyektor. Media pembelajaran ini sangat efektif digunakan untuk meningkatkan hasil belajar Agama Islam pada materi shalat fardhu.

\section{PENUTUP}

Berdasarkan hasil penelitian, pengembangan dan pembahasan yang telah dikemukakan sebelumnya, maka dapat'; disimpulkan

Produk berupa media pembelajaran interaktif Agama Islam berbasis Macromedia Flash Professional 8 dengan materi Shalat Fardhu Kelas III SD Swasta IKAL Medan memiliki hasil sudah layak menjadi produk akhir yang dapat disebarluarkan dan diimplemantasikan kepada para pengguna. Hal ini diperjelas dengan beberapa tahapan ujicoba, baik uji coba dari ahli materi, uji coba ahli desain pembelajaran, uji coba ahli media / desain grafis, uji coba perorangan, uji coba kelompok dan uji coba lapangan rata-rata kategorinya semua sangat baik.

Media pembelajaran Agama Islam berbasis Macromedia Flash Professional 8 dengan materi Shalat Fardhu hasil belajarnya lebih tinggi dari pada hasil belajar Agama Islam dengan materi Shalat Fardhu pada Kelas III SD Swasta IKAL tanpa menggunakan media pembelajaran interaktif Macromedia Flash Professional 8. Media pembelajaran Agama Islam berbasis Macromedia Flash Professional 8 lebih efektif digunakan untuk meningkatkan hasil belajar Agama Islam dengan materi Shalat Fardhu Kelas III SD Swasta IKAL Medan

\section{DAFTAR PUSTAKA}

Andrisa 2007.Student Guide Series Macromedia Flash.Jakrta : Alex Media Komputindo Gramedia.

Arif, Arifuddin. 2008. Pengantar Ilmu Pendidikan Islam.Jakarta : Kultura

Arief S Sadiman, dkk. 2002. Media Pendidikan. Jakarta: Raja Grafindo.

Arsyad, Azhar, 2005. Media Pembelajaran. Jakarta: Raja Grafindo Persada.

Arsyad, Azhar, 2000. Media Pengajaran. Jakarta: Raja Grafindo Persada.

Danim, sudarwan dan khairil, 2010. Profesi Kependidikan. Bandung: Alfabeta.

Dick, W. dan Carey, L, 2005. The Systematic Design of Instruction. United States Of America: Scott Foresman and Company.

E.Gredler, Margaret., 2011. Teori dan Aplikasi. Jakarta : Kencana

Evelin, Nara, Hartini., 2010. Teori Belajar dan Pembelajaran. Jakarta : Ghalia Indonesia

Fathurrohman, P., dan Sutikno, S., 2007, Strategi Belajar Mengajar, Bandung: Refika Aditama.

Hakim, L. 2004. Cara Ampuh Menguasai Macromedia Falsh Professional 8.0 Jakarta: Alex Media Komputindo.

Jaya,Indra.,2013. Penerapan Statistik Untuk Pendidikan. Medan : IKAPI

K.Hamid,Abdul.,2009.Teori Belajar dan Pembelajaran.

Nata, Abuddin., 2009. Perspektif Islam Tentang Strategi Pembelajaran. Jakarta: Kencana.

Mukhtar dan Iskandar. 2009. Orientasi Baru Supervisi Pendidikan, Bandung: Remaja Rosdakarya.

Oemar, Hamalik. 1994. Media Pendidikan. Bandung: Citra Aditya Bakti

Sumanto, W. 1983. Psikologi Pendidikan. Jakarta : Bina Aksara.

Slameto. 2002. Belajar dan factor-faktor yang mempengaruhinya. Jakarta: Rineka cipta.

Usman, Moh. Uzer. 2002. Menjadi Guru Profesional. Bandung: Remaja Rosdakarya 
Purwanto, M. Ngalim. 2002. Ilmu Pendidikan Teoritis dan Praktis. Bandung: Remaja Rosdakarya.

Sudjana dan Rivai. 2005. Media Pengajaran. Bandung: Sinar Baru Algensindo

Sardiman, A.M . 2006. Interaksi dan Motivasi Belajar Mengajar. Jakarta: Rajawali.

Siddik, Dja'far. 2006. Konsep Dasar Ilmu Pendidikan Islam. Jakarta: Citapustaka Media.
Suparman, Atwi.,2004. Desain Instruksional Modern. Jakarta : Erlangga

Smaldino, E. S., dkk. 2008. Instrucional Technology and Media For Learning. New Jersey: Upper Saddle River.

Tim Pengembang Ilmu Pendidikan. 2007. Ilmu dan Aplikasi Pendidikan. Jakarta : Grasindo. 